EMBRYARIDDLE
Aeronautical University

SCHOLARLY COMMONS

\section{International Journal of Aviation,} Aeronautics, and Aerospace

\title{
C02 Reduction Measures in the Aviation Industry: Current Measures and Outlook
}

\author{
Florian Mathys \\ ETH Zurich, mathysf@student.ethz.ch \\ P. Wild \\ ETH Zurich, wildp@ethz.ch \\ J. Wang \\ ETH Zurich, jing.wang@ifu.baug.ethz.ch
}

Follow this and additional works at: https://commons.erau.edu/ijaaa

Part of the Aviation Commons, Operational Research Commons, Sustainability Commons, and the Technology and Innovation Commons

\section{Scholarly Commons Citation}

Mathys, F., Wild, P., \& Wang, J. (2021). CO2 Reduction Measures in the Aviation Industry: Current Measures and Outlook. International Journal of Aviation, Aeronautics, and Aerospace, 8(2).

https://doi.org/10.15394/ijaaa.2021.1581

This Article is brought to you for free and open access by the Journals at Scholarly Commons. It has been accepted for inclusion in International Journal of Aviation, Aeronautics, and Aerospace by an authorized administrator of Scholarly Commons. For more information, please contact commons@erau.edu. 
To protect our global climate, the climate conference of the United Nations defined the so-called Paris Agreement in 2015 in Paris, which postulates that global warming should stay under $2^{\circ}$ Celsius. In addition, further efforts should be made for a temperature increase limit of $1.5^{\circ}$ Celsius (EU, 2020a).

This article focuses exclusively on $\mathrm{CO}_{2}$ emissions. As the interaction of $\mathrm{CO}_{2}$ with the climate is the best investigated pollutant, the quantity of available data is very high. Therefore, this paper determines which $\mathrm{CO}_{2}$ reduction measures exist or will exist in the global aviation industry and discusses their effectiveness.

According to the International Energy Agency (IEA, 2020), the aviation industry alone produced $2.8 \%$ of global $\mathrm{CO}_{2}$ emissions from fossil fuel burning in 2019. To reduce the emitted $915 \mathrm{Mt}$ of $\mathrm{CO}_{2}$ by the worldwide aviation industry (IATA, 2019), the International Air Transport Association (IATA, 2020a) proclaimed to halve the net $\mathrm{CO}_{2}$ emissions by 2050 relative to 2005, which amounted to $416 \mathrm{Mt}$ of $\mathrm{CO}_{2}$ (Macintosh and Wallace, 2008). However, the emissions rate has already grown by $120 \%$ since 2005 . Nevertheless, since 1990 , reduction measures implemented in the aviation industry, such as new technologies, improved operational measures, and more efficient infrastructures, have reduced $\mathrm{CO}_{2}$ emissions by $8.5 \mathrm{Gt}$ (Boyd, 2020).

Every kilogram of fuel burned produces $3.16 \mathrm{~kg}$ of $\mathrm{CO}_{2}$ (EASA, 2019). With a usual seat load factor of $80 \%$ and an average flight speed of $800 \mathrm{~km} / \mathrm{h}$, the consumption value per passenger is around 3.3 liters of kerosene per 100 flight kilometers, including increased consumption due to baggage and cargo in the belly (BAZL, 2015). The density of kerosene leads to emissions of $8.34 \mathrm{~kg}$ of $\mathrm{CO}_{2}$ per passenger for every 100 flight kilometers. Therefore, another objective is to stabilize the net $\mathrm{CO}_{2}$ emission at the level of 2020 with a decarbonized growth. However, the goals explained at the beginning to halve the net $\mathrm{CO}_{2}$ emissions by 2050 could not be achieved by just reducing emissions (Rogelj et al., 2018). Additionally, not all mankind contributes to the $\mathrm{CO}_{2}$ emissions of aviation, as only $2 \%$ to $4 \%$ of the global population flew internationally in 2018 , and only $1 \%$ of the world population is responsible for $50 \%$ of $\mathrm{CO}_{2}$ from commercial aviation (Gössling \& Humpe, 2020). In addition, long-haul flights are estimated to account for $79 \%$ of all $\mathrm{CO}_{2}$ emissions, even though the passenger volume is only $22 \%$; whereas short-haul flights account for $78 \%$ of the passenger volume, with emissions of just $21 \%$ (Brülhart et al., 2020).

For reasons of clarity and to achieve the previously mentioned goals, IATA (2020a) has implemented a four-pillar strategy, which allows us to categorize the improvements and reduction measures into four areas: technology, operations, infrastructure, and market-based measures/political aspects.

This article merges and evaluates the fragmented solution approaches of stakeholders for proposed reduction measures into a clearly structured overview. To reach this objective, an extensive literature review and personal interviews with 
experts are conducted. The solutions for sustainable aviation must on the one hand reduce the $\mathrm{CO}_{2}$ emissions and on the other hand be technically feasible, safe, certifiable, accepted by passengers, and possess a positive cost-benefit ratio.

\section{Technology Measures}

To understand how technology affects aircraft emissions, the interaction between the four forces of flight should be kept in mind. For example, improving the aerodynamics of an aircraft produces less drag, and as a result, less thrust is necessary, which leads to fewer $\mathrm{CO}_{2}$ emissions. Simply stated, improving aerodynamics will increase thrust and lift and decrease drag and weight. The place of action that causes emissions is the jet engines. How many emissions a twinengine aircraft produces during one flight hour in cruise is shown in Figure 1. Other greenhouse gases and pollutants are also emitted, apart from $\mathrm{CO}_{2}$.

\section{Figure 1}

Emissions of a Typical Passenger Aircraft During One Hour in Cruise (Rindlisbacher, 2020)

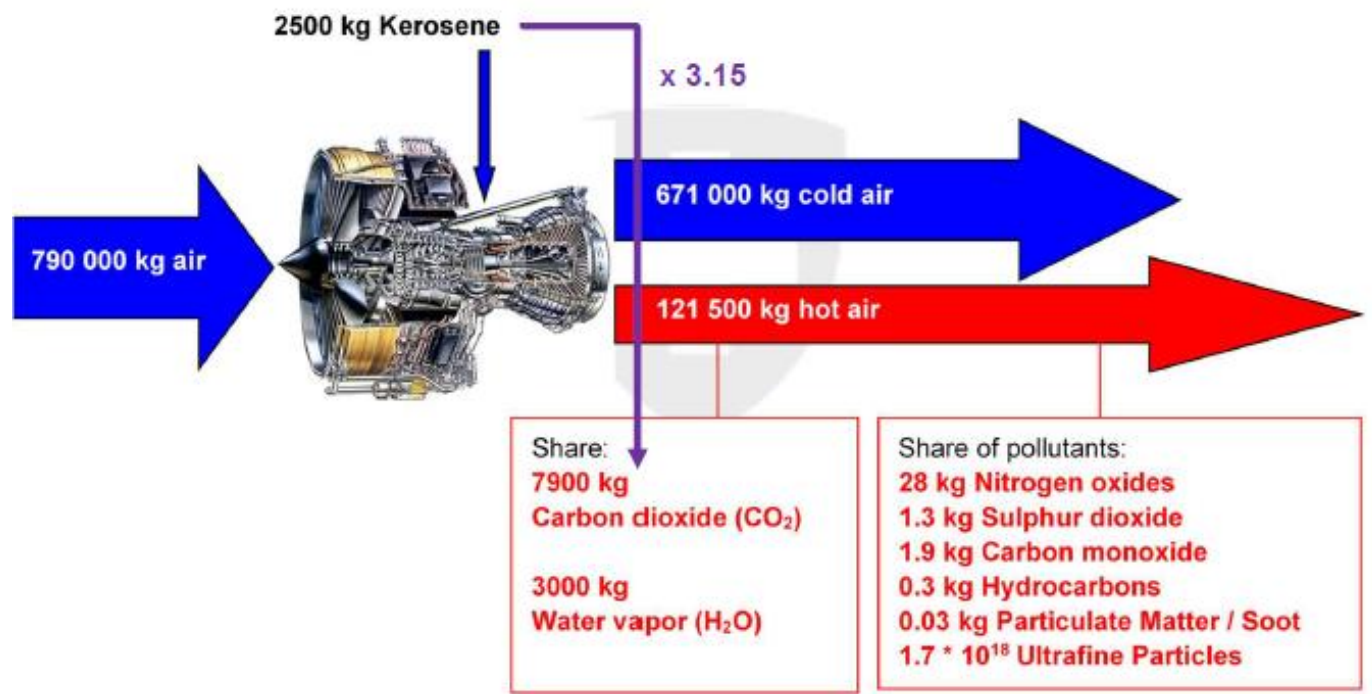

The fossil fuel consumption of today's commercial aircrafts is already around $70 \%$ less than it was 30 years ago (BAZL, 2015). However, the cost-benefit ratio for further progress with the current technology is gradually being exhausted.

\section{Efficiency of Current Aircraft Models}

The main objective of the functions in aircraft design is to decrease fuel consumption with economically appropriate technologies. According to Clean Sky (2020), an airline aircraft has a lifetime of 15-20 years, necessitating renewal of the fleet from time to time, with the most fuel-efficient aircraft. An aircraft also deteriorates over time and causes a fuel bias of $1 \%$ per 6,000 hours (Wild, 2018). 
Notably, the aircraft and engine are manufactured by separate companies, and compatibility between aircraft and engine is produced through close collaboration.

The efficiency improvement shows the efficiency of the entire aircraft system, which means the updates consist of aerodynamic improvements, such as winglets and more efficient jet engines. A detailed list of current efficiency improvements for short-haul and long-haul aircraft is available from IATA (2020b).

As a rule of thumb, engine improvements increase by $1 \%$ each year ( $\mathrm{P}$. Wild, personal communication, October 06, 2020). Considering the lifetime of an aircraft, the latest steps of this technology generation have led to around $20 \%$ more efficiency (L. Weibel, personal communication, November 04, 2020). One of the most important developments in engine technologies in the last decade is the geared turbofan. In a conventional turbofan, the fan and the low-pressure shaft are directly connected; however, in the geared turbofan, there is a gear located between them, which allows both components to rotate at their different optimal speeds, thus leading to a higher degree of efficiency. This technology step alone reduces fuel consumption by $35 \%$ compared to the conventional turbofan from 2000 (Sieber, 2020).

An observable trend for long-haul, wide-body aircrafts is that airlines no are longer purchasing four-engine aircrafts like the A380 from Airbus or the Boeing 747. One reason for this change is that the high passenger capacity is not exploited, which turns, for instance, the A380 from being one of the most fuel-efficient aircrafts to one of the worst (Rutherford, 2018).

Another reason why twin-engine aircraft have gained popularity for longhaul transoceanic flights is the higher range of extended-range twin-engine operational performance standards (ETOPS) due to the higher safety standard. ETOPS is a certification that allows twin-engine aircrafts to fly routes where an alternative airport for emergency cases is further than 60 minutes away (Sheffield, 2020). ETOPS is not applied to quad-engine aircraft because if one engine fails, the aircraft is still able to continue the flight safely with three engines running. A higher ETOPS range, combined with enough belly freight capacity, enables the aircraft to replace four-engine aircrafts, even for trans-pacific flights (Rutherford, 2018).

\section{Future Aircraft Aerodynamics and Propulsion Design}

To break down the technological improvements for the next decades, it makes sense to split them according to the categories of evolutionary and revolutionary aircraft technologies (IATA, 2020c). Evolutionary technologies are those that can be adapted to classical tube and wing aircrafts with jet-fuel engines, including the advanced turbofan engine, natural/hybrid laminar flow, and new engine core concepts. It is estimated that evolutionary upgrades will produce $\mathrm{CO}_{2}$ emission savings of up to $30 \%$ by 2035 . By contrast, revolutionary technologies use completely new technologies and design concepts. From the propulsion 
perspective, there are open rotor engines, hybrid-electric aircrafts, and fully electric aircrafts. From an aerodynamic perspective, improvements can be achieved by developing blended-wing body aircrafts or strut-braced wings.

The improvements in advanced turbofan engine technology go hand-inhand with the new engine core concepts. A characteristic measurement to show the improvements is the bypass ratio (BPR), which specifies the amount of air that bypasses the engine core with the air streaming through the core of the engine, respectively, the combustion chamber. Earlier engines had a BPR ranging from 5:1 to 6:1 (IATA, 2020c). With the newer engine generation like the "GE9X" on the Boeing 777X, a BPR of 10:1 is possible, with a reduced fuel consumption of $10 \%$ (MTU, 2020).

The blended wing body aircraft represents a completely different approach to aircraft design. This type of aircraft is a large wing, with the passenger cabin and cargo load positioned in the middle section. The fuselage and wings are just one element of the aircraft that makes the whole aircraft generate lift. Thus, the fuel efficiency improvements are forecasted at around 27\%-50\%. Further benefits include shorter turnaround times, less noise, and larger available cargo volume. However, developing these aircraft requires changes to the current infrastructure and high investments, and high uncertainties in the design process need to be overcome (IATA, 2020c). In addition, the passenger acceptance is questionable, and how the aircraft should be evacuated has not yet been clarified (M. Immer, personal communication, October 28, 2020).

Electric propulsion with an efficiency degree of 95\% (Rindlisbacher, 2020) offers new degrees of design freedom (Moore \& Fredericks, 2014), whether the energy comes from batteries (fully electric aircraft) or from a gas engine (hybridelectric aircraft), especially in the number of engines, meaning aircrafts with more than four engines could be developed. Battery-electric propulsion produces no emissions during flight, particularly when batteries are charged with renewable energy. Although the degree of efficiency for electric propulsion is twice that of a gas turbine, the potential for commercializing battery-electric aircraft is low due to the small energy density of the battery with $0.25 \mathrm{kWh} / \mathrm{kg}$ (Sieber, 2020) compared to the $12 \mathrm{kWh} / \mathrm{kg}$ (IPCC, 2020) from conventional jet fuel. In addition, the charging time for a short-haul aircraft would be long, thus lengthening turnaround times. With the high number of load cycles, the battery lifetime is very limited (Rindlisbacher, 2020).

\section{Hydrogen Technology in Propulsion Design}

The combustion of hydrogen is a carbon-free process that emits mainly water vapor. Hydrogen as a propulsion method can be used as a fuel for aircrafts when it is combusted directly in a hydrogen burning engine, as in a conventional jet engine, or reacts in a fuel cell powering electric motor (Clean Sky, 2020). The liquid hydrogen energy density per mass is $33.3 \mathrm{kWh} / \mathrm{kg}$, around three times higher 
than kerosene, but the volumetric density is $2.3 \mathrm{kWh} / 1$, four times smaller (IPCC, 2020). To decrease the volume of gaseous hydrogen to liquid hydrogen, a lot of energy is needed to cool the liquid hydrogen to $-253^{\circ} \mathrm{C}$. Nevertheless, large tanks, which should be safe, are needed on board an aircraft, which significantly increases the operating weight (Clean Sky, 2020). However, the empty weight of the hydrogen tanks is thought to be higher than that of the tanks for kerosene-based systems, making them particularly unsuitable for long-haul flights.

As hydrogen propulsion emits water vapor instead of $\mathrm{CO}_{2}$, other inflight emissions and effects like $\mathrm{NO}_{\mathrm{x}}$ and contrails are also reduced compared to kerosene powered aviation. In particular, fuel cells emit less $\mathrm{NO}_{\mathrm{x}}$ and leave fewer contrails compared to the hydrogen turbine, because the latter still produces some $\mathrm{NO}_{\mathrm{x}}$, and the water vapor from a fuel cell is cooler and more controllable. With the new development of fuel cells to a two to three times higher power density, the efficiency of fuel cells is better than that of hydrogen-burning engines regarding the lower heating value (Clean Sky, 2020).

In a hydrogen-powered aircraft, the fuel cell converts hydrogen into electric energy, which powers an electric motor. The process with the highest potential in the aviation sector is low-temperature proton-exchanged membrane fuel cells (PEM fuel cells) (Clean Sky, 2020). The current power density of fuel cells is between 1 and $2 \mathrm{~kW} / \mathrm{kg}$ (Sieber, 2020), but for efficient usage in an aircraft, it requires a two to three times higher power density (Clean Sky, 2020).

The industry relies on hydrogen powered aircrafts. For instance, in September 2020, ZeroAvia (2020) conducted the world's first hydrogen fuel cellpowered flight containing a full traffic pattern in a Piper M-class. Furthermore, DLR (2020) is developing twin-engine Dornier 228 demonstrators with hydrogen fuel cells and electric propellor propulsion, and the maiden flight is planned for 2026. The hydrogen concept of Airbus's "Zero emissions" program consists of three different concepts: "Turboprop," "Blended-Wing Body," and "Turbofan," which are either powered with hybrid turboprop engines or with hybrid turbofan engines (Airbus, 2020a). The newest "Turboprop" concept intends six removable engines, the so-called "pods," with the propellors driven by electric motors. The electricity comes from hydrogen fuel cells (Airbus, 2020b). This ambitious goal of Airbus is to bring the first commercial aircraft with hydrogen propulsion onto the market by 2035 (Airbus, 2020a).

Additional benefits of hydrogen-powered aircrafts are that the maintenance activities for electric motors are less frequent and less costly compared to combustion engines. The aircraft design from existing aircrafts could also be used (IATA, 2020c). However, the turnaround times on the ground are longer due to the longer refueling process (Clean Sky, 2020). The biggest challenges for hydrogenpowered aircraft are hydrogen storage in the aircraft and the introduction of a new hydrogen infrastructure on the ground (Sieber, 2020). 


\section{Sustainable Aviation Fuels (SAF)}

Since the implementation of revolutionary technologies requires time for development and therefore carbon-neutral growth is not yet possible, another solution like SAF is needed, which can be implemented more quickly. SAF is a generic term for biofuels, alternative fuels, and synthetic fuels. Instead of emitting new $\mathrm{CO}_{2}$ into the atmosphere with fossil fuels from crude oil, SAFs are a way to close the $\mathrm{CO}_{2}$ cycle. The $\mathrm{CO}_{2}$ is stored in organic materials, and with approved production processes, the material is converted into $\mathrm{SAF}$, which releases $\mathrm{CO}_{2}$ when it is burned. Hence, the lifecycle emissions of $\mathrm{CO}_{2}$ can be reduced by up to $80 \%$ (IATA, 2020c). SAF can be produced, for instance, from household waste, cooking oil, or halophytes that are growing in saltwater. If the production of SAF conflicts with food production, destroys forests, or consumes too much fresh water, SAF is no longer sustainable but destructive (IATA, 2020d). Using the sun-to-liquid process or the power-to-liquid process, the production of SAF is possible with a net zero of $\mathrm{CO}_{2}$ emissions.

The aviation sector already uses SAF for their operations. Starting in 2015, with a volume of 0.5 million liters, over 250,000 flights from 40 airlines have been conducted with SAF (IATA, 2020d). Considering the total fuel consumption of 363 billion liters in 2019 (Mazarenau, 2020), the usage of SAF is undoubtedly negligible. But the demand for SAF is rising and is forecasted to reach 43 million liters by 2020 . As the growth of demand is exponential and production factories could produce $\mathrm{SAF}$ on a bigger scale, the market could be served with seven billion liters by 2025 (IATA, 2020c), which would be around 2\% of the total fuel consumption in 2019.

The current major challenge of SAF is that the amount of production is small, and the price of a liter of SAF is still too high. For an airline, the main cost factor today is the fuel cost, making up to $40 \%$ of the budget (Wild, 2020). With the current price of SAF, which is between three (Compensaid, 2020) and four times (Patt, 2019) higher than fossil fuels, it makes no sense to use it from an economical perspective. However, with a larger-scale deployment due to the decreased price, the usage of SAF becomes more feasible, affordable, and available. With conductive projects from the public sector, together with regularities, incentives, or subsidies, as is already conducted with wind and photovoltaic energy, a faster way to build more efficient production factories is possible (IATA, 2020c). Hence, the demand for SAF can be saturated with a price at the level of conventional jet fuel.

The participation of revolutionary technology regarding the goals of 2050 is very late, especially if considering the long certification procedure, which lasts around 10 years in the aviation sector due to safety reasons. Therefore, SAF is a suitable bridging solution to allow carbon-neutral growth. 


\section{Operations Measures}

Operations reduction measures are feasible with the current stand-in technology. Operators or users, such as airlines, are able to optimize their processes and procedures regarding $\mathrm{CO}_{2}$ emissions in their daily business operations.

\section{Intermodal Traffic/Mode Shift}

An acceptable $\mathrm{CO}_{2}$ reduction measure is to change the mode of transport for domestic travel or travel in adjacent countries to a more ecological transport mode, for instance, train travels replacing short-haul flights. A plane/train comparison made by ETHZ (2020) of the parameter travel time and $\mathrm{CO}_{2}$ emissions from Switzerland to neighboring countries showed that travel by train produces at least two times less $\mathrm{CO}_{2}$ than by an aircraft. If the train operates with electricity from renewable energy options, the effect of the mode shift is even higher. The travel times are also comparable, except to further away capital cities like Berlin and Vienna, where currently no high-speed trains are operating. The price component is not considered, but it is a relevant decision factor for passengers.

\section{Weight Reduction}

With every additional ton of weight on an aircraft, more fuel is necessary. For a short-haul flight, this amounts to between $3 \%$ and $10 \%$, and for a long-haul flight, it amounts to $20 \%-25 \%$ of extra fuel (Wild, 2018).

Table 1 lists the different weight-reduction measures with the savings per aircraft. Considering only one single measure, the savings are not immense; however, given that an aircraft flies several times a day, these savings have a largescale effect.

\section{Table 1}

Weight Reduction Measures

\begin{tabular}{|l|c|}
\hline Measures & Savings [kg] \\
\hline Newer external paintings & $100-200$ \\
\hline Excess customer service items like books, magazines, headsets & $20-160$ \\
\hline Thinner, carbon-fiber seats; per seat & $4-5$ \\
\hline Limited duty-free sales (online pre-ordering) on short/long-haul & $48 / 60$ \\
\hline Uniform cargo load devices & Up to 240 \\
\hline
\end{tabular}

Note. Source: Wild (2018). 


\section{Flight Planning and Fuel Calculation/Aircraft Procedures}

Flight planning should be optimized by the aircraft operator with respect to the optimal flight route, altitude, speed, and payload. The goal of an optimized flight profile is to reach cruise altitude quickly and leave this altitude as late as possible for the approach (M. Immer, personal communication, October 28, 2020). Using the optimal operating point according to the ratios of payload and range, an aircraft could be operated more efficiently.

Reliable planning should contain statistical evaluation tools, flight level optimization, precise weights, precise performance data for each aircraft, integrated track optimization, and cost index optimizations, leading to savings of between $1 \%$ and 2\% (Wild, 2018). The guideline for general improvements is cost-effective, but at least on the same safety level as previous technology (L. Weibel, personal communication, November 04, 2020). The cost index optimizations should also consider the emission footprint. From an ecological perspective, route planning, as in the following example, should be avoided. In this specific case, for a flight from Warsaw (Poland) to Rome (Italy), it is cheaper for an operator to fly a detour with burning $115 \mathrm{~kg}$ more fuel than the shorter fuel optimized routing with a higher route charge of 109 euros (EUROCONTROL, 2020a).

What also applies to the fuel calculation is that, with every additional ton of fuel on board, additional fuel is needed. The fuel policy boundaries are set by the European Union Aviation Safety Agency (EASA). The main improvements in fuel calculations could be made with the contingency fuel and the extra fuel. A decision tool for the extra fuel amount is served by a statistical evaluation tool. Thereby, the $95^{\text {th }}$ quantile of the extra fuel amount of all flights to a destination within one year is considered (Wild, 2018), but it is not easy to conduct such a statistical evaluation due to data protection regulations concerning cockpit members (L. Weibel, personal communication, November 04, 2020). With a new regulation regarding contingency fuel, a fuel reduction of around $1 \%$ is possible. Another adjustment for the fuel calculation could be made according to the latest payload information because for commercial flights, "no-shows" of passengers can occur. With less weight onboard from the passenger and baggage, less fuel is necessary. This improvement has a greater impact on long-haul flights than on short-haul flights (Wild, 2018).

If the engines of an aircraft are not running, the auxiliary power unit (APU) powers the aircraft with external power. Although today's APU is further developed and more efficient than the predecessors (Wild, 2018), the use of a diesel ground power unit (GPU) or fixed energy system produces fewer $\mathrm{CO}_{2}$ emissions by a factor of 17 (GPU) or 480 (fixed energy system) (Fleuti \& Ruf, 2018). Using the GPU as a procedure requires the necessary infrastructure and reduces, besides 
emissions, the maintenance cost of the APU (L. Weibel, personal communication, November 04, 2020).

\section{Infrastructure/ATM}

ATM contributes to navigational improvements and a more efficient use of airspaces to reduce total flight times. To modernize the European airspace, especially to reorganize the fragmented airspaces, the EU commission developed an initiative called "Single European Sky ATM research program (SESAR)" with the European air traffic controller EUROCONTROL. The main goal is to merge the large number of airspaces to reduce at least $10 \%$ of $\mathrm{CO}_{2}$ emissions (SESAR, 2020a), thereby giving an average fuel reduction per flight estimated at 250-500 $\mathrm{kg}$ (SESAR, 2020b). With more efficient taxi operations, fuel savings of 38-75 kg per flight (relative reduction 30\%) are targeted (SESAR, 2020b). The equivalent modernization process for US airspace is called NextGen (FAA, 2020).

The following paragraphs present some components to reach the $\mathrm{CO}_{2}$ reduction goal of $10 \%$, introducing, in particular, a lean and efficient use of air navigation services (ANS) with increased collaboration and operational predictability and improved flight trajectories.

The concept of 4D navigation, which uses the three spatial dimensions and the time dimension, allows the introduction of a trajectory of a flight. With overlaying trajectories of different flights, conflicts and holdings could be noticed earlier and could be prevented entirely so that every aircraft is able to fly their optimal trajectory at the preferred cruise level for as long as possible. As a result, emissions are reduced due to the decreased flight time. The challenge is that ANS providers and aircrafts need new technical equipment. Also, the controller must be aware of what impact an influencing factor has on the whole trajectory, which is particularly difficult when the equipment fails and could lead to a workload for the controller (Skybrary, 2017).

With improved vertical navigation, such as continuous climb and descent operations instead of climb step operations, a fuel reduction of $163-325 \mathrm{~kg}$ per flight (relative reduction 10\%) is possible (SESAR, 2020b). In Europe alone, the potential for optimized departure and approach operations is up to 1.1 million tons of $\mathrm{CO}_{2}$ per year (Skyguide, 2020). According to Wild (2018), the vertical separation minimum between FL290 and FL410 was reduced in 2002 from 2,000 ft to 1,000 $\mathrm{ft}$ due to more precise navigational equipment. This reduction resulted in an increased capacity of $14 \%$, but the aircraft was able to fly more at its optimized altitude, which reduced its $\mathrm{CO}_{2}$ emissions. Therefore, any holdings should be conducted at the highest reasonable altitude or even better to reduce speed and avoid holdings. However, in the longest flight phase of cruise, the optimum altitude should be targeted where the lift drag ratio is at a maximum for the chosen speed. Consequently, the altitude should be changed during the cruise because flying 
lower or higher uses more fuel and the aircraft produces more $\mathrm{CO}_{2}$ emissions (Wild, 2018).

Improvements in horizontal navigation can be achieved with free route airspaces (FRA), leading to more direct routes. The concept provides that a user of an aircraft is able to plan a route freely with or without intermediate waypoints in a specific airspace while considering the boundaries of a defined entry and exit point. Inside free airspaces, flights are still under air traffic control. The horizontal limits exist regardless of Flight Information Region (FIR) or country borders, and the vertical-level limit is dependent on the particular FRA (Todorov, 2019). The average en-route fuel savings amount to $50-100 \mathrm{~kg}$ per flight, which represents a relative reduction up to $2.5 \%$ (SESAR, 2020b). An early trial to defragment the European airspaces in nine functional airspace blocks failed because of "a lack of commitment on the part of the member states to preserve sovereignty, the legacy of national air navigation service providers, revenues, and workforce" (Tani, 2017). A collaboration between European countries is, with a standardization of data and radar data, technically feasible. Financial and political aspects are a hurdle in this process (P. Truffer, personal communication, November 11, 2020).

\section{Market-based Measures/Political Aspects}

Not paying fuel tax or VAT on commercial international flights is a rule that goes back to the foundation of the International Civil Aviation Organization (ICAO Chicago Convention, Article 24) in 1944 (ICAO, 1944) to promote civil aviation, and because the aviation industry pays for its infrastructure mostly by itself (BDL, 2020). According to the model developed by Faber et al. (2019), without tax exemptions, the average ticket price increases by $10 \%$, and passenger demand decreases by $11 \%$. Consequently, besides the emissions decline of $11 \%$, the falling demand has a negative impact on employment in the aviation sector, but the higher fiscal revenue offsets this impact. In the end, a negligible effect on employment and gross domestic product (GDP) is observable.

The aviation industry is a global business. Therefore, competition boundaries, such as political boundaries or public awareness, should be treated in a similar way for every operator globally. A fair competition without distortion is a main motivation for accepting market-based measures (D.-H. Lee, personal communication, October 28, 2020).

\section{Area-wide Compensation Systems (EU ETS/CORSIA)}

Area-wide compensation systems act under the principle that "the polluter pays." The European Emission Trading System (EU ETS) is an emission trading system constrained to Europe that has been active since 2005 as the first major carbon market. It remains the biggest carbon market, and it uses a Cap \& Trade system to monitor companies with high $\mathrm{CO}_{2}$ emissions and other pollutants, such as heavy energy-using installations and, since 2012, airlines. Until the end of 2023, only flights in the European Economic Area will be affected. The cap is fixed on 
the total amount of emissions and will be decreased yearly. A polluter needs certificates as an allowance to emit, for instance, a ton of $\mathrm{CO}_{2}$. These certificates can then be traded with other companies to cover all their emissions. If a company does not have enough certificates at the end of each year, a big fine is distributed. The goal is for companies to invest in clean, low-carbon technologies (EU, 2020b). The price for a carbon certificate from the EU ETS in the years between 2008 and 2019 fluctuated between 5 and 30 euros per ton $\mathrm{CO}_{2}$ (Vollebergh \& Brink, 2020). To achieve the objective of the Paris Agreement, a price of up to 100 USD per ton $\mathrm{CO}_{2}$ is needed to reduce emissions with this mechanism (Rogelj et al. 2018).

Another market-based approach to reduce $\mathrm{CO}_{2}$ emission is called "offsetting." For that reason, in 2016, ICAO resolved a compensation system called Carbon Offsetting and Reduction Scheme for International Aviation, or CORSIA for short. Compared to the EU ETS, CORSIA focuses solely on international air transport and is the first globally active climate protection instrument in the transport and economy sector. The CORSIA program comprises three phases, where the pilot phase (2021-2023) and the first phase (2024-2026) are voluntary for the member states, while the second phase (2027-2035) is mandatory for all 193 member states, with some exceptions. The program is running until 2035 (ICAO, 2020).

Companies receive compensation when they acquire eligible emission units from $\mathrm{CO}_{2}$ offsets of climate protection projects in other sectors, such as renewable energy projects. The climate protection projects are certified and examined after international standards. Projects in emerging and developing countries, which have a large potential to reduce $\mathrm{CO}_{2}$ emissions, are particularly taken into account. A possible way to merge the EU ETS and CORSIA is unknown (BAZL, 2020). The funding for climate projects with CORSIA is forecasted to be 40 billion USD and offsets 2.6 billion tons of $\mathrm{CO}_{2}$ between 2021 and 2035 (ICC, 2019).

\section{Flight Taxes}

In this article, the term "flight tax" refers to a ticket tax that is charged from the departure destination. The objective of a flight tax is to use demand elasticity in the aviation sector. With a higher ticket price, fewer people would fly, and therefore, an overall reduction of flights and their emissions occurs. As specified by Faber et al. (2019), 14 countries in Europe and 19 countries outside of Europe already use a flight tax on domestic and international flights. The average burden per passenger in Europe is around 15 euros, with a range between 40 euros (United Kingdom) and 1 euro (Croatia). EUROCONTROL (2020b) investigated the effects of flight tax only on aviation $\mathrm{CO}_{2}$ emissions and found that the implementation of a ticket tax in countries such as the United Kingdom, Germany, and Italy has shown only a limited effect in decreasing emissions. In relation to the total growth of the aviation sector in particular countries for 2010-2019, the effects of a flight tax are almost negligible. Further, the passenger number reduction per flight due to the 
flight tax is not significant enough to force an airline to not operate that flight ( $\mathrm{P}$. Wild, personal communication, October 06, 2020). In addition, the impact on the seat load factor is not high enough to change operations to smaller aircraft.

Estimated effects on demand with the implementation of a flight tax are based on the example of Switzerland in Brülhart et al. (2020). In general, passengers are more price sensitive if they are more flexible, especially for shorthaul and economy-class flights. With other demand elasticities, different scenarios are simulated, resulting in air traffic reductions decreasing to $20 \%$ and greenhouse gas emissions decreasing to $10 \%$. With this mitigation, Switzerland's total global warming impact decreases to $2 \%$. However, with the demand growth of the aviation sector, this positive impact regarding emissions savings would be offset within three years. The revenues of this flight tax are estimated to be up to 0.9 billion USD per year.

\section{Conclusion}

IATA proclaimed to halve the net $\mathrm{CO}_{2}$ emissions by 2050 compared to 2005 , despite a forecasted growth in the aviation sector. Hence, the growth should be decarbonized and, for the moment, stabilized at the forecasted pre pandemic $\mathrm{CO}_{2}$ emissions level of 2020. This paper investigates the various current and future $\mathrm{CO}_{2}$ reduction measures in the global aviation industry and shows their effectiveness. Figure 2 illustrates a holistic evaluation of mitigation measures in a time period/potential matrix. The horizontal direction shows the potential or impact of a reduction measure. The time period in vertical direction represents when the reduction measure would be implemented. 
Figure 2

Evaluation Matrix

\begin{tabular}{|c|c|c|c|c|}
\hline \multirow{2}{*}{\multicolumn{2}{|c|}{$\begin{array}{l}\mathrm{SH}=\text { Short-haul } \\
\mathrm{LH}=\text { Long-haul }\end{array}$}} & \multicolumn{3}{|c|}{ Potential / Impact } \\
\hline & & Low & Medium & High \\
\hline \multirow{3}{*}{ 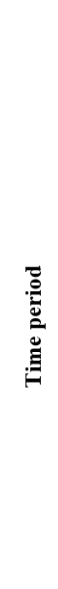 } & $\begin{array}{l}\text { Short-term } \\
\text { until } 2025\end{array}$ & $\begin{array}{l}\text { - Synthetic fuels } \\
\text { - SH: Mode shift } \\
\text { - Procedures of ATM } \\
\text { - EU ETS / CORSIA / Flight tax }\end{array}$ & $\begin{array}{l}\text { - Bio fuels as blending } \\
\text { - Weight reduction } \\
\text { - Flight planning and fuel calculation } \\
\text { aircraft procedures }\end{array}$ & \\
\hline & $\begin{array}{c}\text { Mid-term } \\
2025-2040\end{array}$ & $\begin{array}{l}\text { - Evolutionary aerodynamic } \\
\text { improvements } \\
\text { - SH: Electric / Hydrogen aircraft } \\
\text { - EU ETS / CORSIA / Flight tax }\end{array}$ & $\begin{array}{l}\bullet \text { Evolutionary engine improvements } \\
\bullet \text { Procedures of ATM }\end{array}$ & - SAF \\
\hline & $\begin{array}{l}\text { Long-term } \\
\text { from } 2040\end{array}$ & - EU ETS / CORSIA / Flight tax & $\begin{array}{l}\text {-SH: Electric aircraft } \\
\text { - LH: Hydrogen aircraft / Blended } \\
\text { wing body aircraft }\end{array}$ & $\begin{array}{l}\text { - SH: Hydrogen aircraf } \\
\bullet \text { SAF }\end{array}$ \\
\hline
\end{tabular}

The implementation of fuel efficiency optimization measures takes time until fleet turnover is planned, especially when considering the long certification time of up to 10 years and the aircraft lifespan of about 15-20 years. Aerodynamic improvements for tube and wing aircrafts are already exhausted; therefore, the potential for further improvement is low. On the contrary, advanced turbofan and new engine core concepts as evolutionary engine improvements have medium potential because the development of jet engines with higher BPRs is still with reasonable expenditure possible. The introduction of an aircraft for short-haul commercial flights using electric motors is to be expected for mid-2030. The motors will be either powered by hydrogen fuel cells or electricity from batteries, whereby the storage of hydrogen is a step ahead regarding operation weight. Hydrogen technology is also more scalable and energy efficient and is the more economic option. Also, conflicting objectives and effects, such as the reduction of $\mathrm{CO}_{2}$ emissions and non- $\mathrm{CO}_{2}$-emissions should be further investigated and not neglected. For instance, with hydrogen, less $\mathrm{CO}_{2}$ is produced, but more water vapor and $\mathrm{NO}_{\mathrm{x}}$ are created. The potential of synthetic fuels is low in the short term due to their small production capacity. However, today's use of biofuels as blending has medium potential to be implemented by 2025 because production growth is on the exponential path. From 2025, SAF has a high potential and impact as $\mathrm{CO}_{2}$ reduction measure. The most promising long-term technologies to reduce $\mathrm{CO}_{2}$ emissions are hydrogen-powered aircrafts and SAF. However, the advantages of SAF and 
hydrogen-powered aircraft outweigh the other options only when the energy used for production is renewable.

A mode shift from flying to taking a train is a reasonable reduction measure for travel to adjacent countries with good train accessibilities. Operation measures, such as weight reduction, flight planning, and fuel calculation, have medium potential in the short term because they are easy to realize and have a big scale effect. With every weight saving, either from fuel or payload, an avoidance of carrying additional fuel is possible because with every further ton on board an aircraft, additional fuel amounting to $3 \%-10 \%$ for short-haul flights and $20 \%-25 \%$ for long-haul flights is needed.

The objectives of the reduction measure from an infrastructure/ATM perspective are to decrease flight times and avoid holdings because every $\mathrm{kg}$ of fuel burned produces $3.16 \mathrm{~kg} \mathrm{CO}$ emissions. The implementation of more efficient airspaces and flight routes in Europe can be achieved by SESAR to reduce at least $10 \%$ of $\mathrm{CO}_{2}$ emissions. While these improvements mitigate only a few emissions, implementing these improvements area-wide create big scale effect. Therefore, the impact is low at first, but increases to medium with time.

Regulations in a free market are necessary when nobody feels responsible for paying the cost for damage like climate warming. By applying "the polluter pays" principle, it might be possible to stop such market failures by implementing market-based measures, such as area-wide compensation systems like EU ETS, CORSIA, and taxes. Studies confirm that market-based measures have a low impact as a reduction measure because prices are too low to obtain a significant reduction. However, with today's offsetting of $\mathrm{CO}_{2}$, the problem is not solved at the root. Therefore, the revenues obtained through these systems may be used to invest in the research and development of more promising reduction measures. Doing so will also raise people's acceptance to pay such market-based measures and provide new jobs. To support $\mathrm{CO}_{2}$ reduction measures, a global approach with standardized rules and reasonable incentives is useful regarding the distortion of competition. The implementation of market-based measures is connected with conflicts of interest regarding ecological, economic, political, and social goals. 


\section{References}

Airbus. (2020a). ZEROe. Retrieved September 29, 2020, from https:// www.airbus.com/innovation/zero-emission/hydrogen/zeroe.html

Airbus. (2020b). These pods could provide a blueprint for future hydrogen aircraft. Retrieved December 16, 2020 from https://www.airbus.com/ newsroom/stories/hydrogen-pod-configuration.html

BAZL. (2015). Was bei Triebwerken hinten herauskommt. [What comes out of the rear of engines]. Retrieved from https://www.bazl.admin.ch/dam/bazl/de/ dokumente/Politik/Umwelt/was_bei_triebwerkenhintenherauskommt.pdf. download.pdf/was_bei_triebwerkenhintenherauskommt.pdf

BAZL. (2020). CORSIA - Carbon offsetting and reduction scheme for international aviation. Retrieved November 05, 2020, from https://www.bazl.admin.ch/bazl/de/home/fachleute/regulation-undgrundlagen/umwelt/marktbasierte-massnahmen/corsia.html

BDL. (2020). Steuern und ticketpreise. Retrieved November 13, 2020, from https://www.klimaschutz-portal.aero/faq/kerosinsteuer/

Boyd, R. (2020). Climate change mitigation. ICAO Environmental Report 2019 Aviation and Environment.

Brülhart, M., Cocker, F., Rohner, D., \& Thalmann, P. (2020). Introducing an airline ticket tax in Switzerland: Estimated effects on demand. Policy Brief. The Enterprise for Society. Retrieved from https://e4s.center/ document/policy-brief-air-ticket-tax/

Clean Sky. (2020). Hydrogen-powered aviation: A fact-based study of hydrogen technology, economics, and climate impact by 2050. Clean Sky Joint Undertaking. Retrieved from https://op.europa.eu/en/publication-detail//publication/55fe3eb1-cc8a-11ea-adf7-01aa75ed71a1/language-en

Compensaid. (2020). Why fly with sustainable aviation fuel? Retrieved from November 16, 2020, from https://compensaid.com/projects/saf

DLR. (2020). DLR und MTU Aero Engines erforschen Flugantrieb mit Brennstoffzelle. [DLR and MTU Aero Engines are researching aircraft propulsion with fuel cells]. Retrieved December 06, 2020, https://www.dlr.de/content/de/artikel/news/2020/03/20200805_dlr-undmtu-aero-engines-erforschen-flugantrieb-mit-brennstoffzelle.html

EASA. (2019). European aviation environmental report 2019. Retrieved from https://www.easa.europa.eu/eaer/

ETHZ. (2020). Map "plane/train comparison with CO2 emissions". Retrieved December 08, 2020 from https://ethz.ch/content/dam/ethz/associates/ services/organisation/Schulleitung/mobilitaetsplattform/Train_Plane_Euro pe_Time and CO2.pdf

EU. (2020a). Paris agreement. Retrieved October 05, 2020, from https://ec.europa.eu/clima/policies/international/negotiations/paris_en 
EU. (2020b). EU emissions trading system (EU ETS). Retrieved November 18, 2020, from https://ec.europa.eu/clima/policies/ets_en

EUROCONTROL. (2020a). Environmental assessment: European ATM network fuel inefficiency study, Edition 01-01. Edition Date: 07.12.2020 Retrieved from https://www.eurocontrol.int/publication/environmental-assessmenteuropean-atm-network-fuel-inefficiency-study

EUROCONTROL. (2020b). Does taxing aviation really reduce emissions? Think Paper \#7 Aviation Intelligence Unit - October 2020. Retrieved from https://www.eurocontrol.int/publication/does-taxing-aviation-reduceemissions

FAA. (2020). Modernization of U.S. airspace. Retrieved November 05, 2020, from https://www.faa.gov/nextgen/

Faber, J., Albers, J., Nelissen, D., Schroten, A., van der Veen, R., Vergeer, R., \& van Wijngaarden, L. (2019). Taxes in the field of aviation and their impact. CE Delft, Final Report for European Commission, June 2019. Retrieved from https://op.europa.eu/en/publication-detail//publication/0b1c6cdd-88d3-11e9-9369-01aa75ed71a1

Fleuti, E., \& Ruf, C. (2018). Aircraft ground energy systems at Zurich Airport, Edition date 14.02.2018. Retrieved from https://www.flughafenzuerich.ch/unternehmen/laerm-politik-und-umwelt/luft

Gössling, S., \& Humpe A. (2020). The global scale, distribution and growth of aviation: Implications for climate change. Elsevier Global Environmental Change, 65, 102194. https://doi.org/10.1016 j.gloenvcha.2020.102194

Graver, B., \& Rutherford D. (2018). Transatlantic airline fuel efficiency ranking 2017. White Paper September 2018 of International Council of Clean Transportation (ICTT). Retrieved from https://theicct.org/ publications/transatlantic-airline-fuel-efficiency-ranking-2017

IATA. (2019). Economic performance of the airline industry. Retrieved from https://www.iata.org/en/publications/economics/

IATA. (2020a). Aviation \& climate change. Carbon offsetting for international aviation. Retrieved from https://www.iata.org/en/programs/environment/ climate-change/

IATA. (2020b). Aircraft technology roadmap to 2050. Version 2020. Retrieved from https://www.iata.org/en/programs/environment/technology-roadmap/

IATA. (2020c). Building new technologies. Retrieved October 13, 2020, from https://www.iata.org/en/programs/environment/technology-roadmap/

IATA. (2020d). Developing sustainable aviation fuel (SAF). Retrieved November 26, 2020, from https://www.iata.org/en/pro grams/environment/sustainable-aviation-fuels/\#tab-2 
ICAO. (1944). Convention on international civil aviation done at Chicago on the $7^{\text {th }}$ day of December 1944. Retrieved November 06, 2020, from https://www.icao.int/publications/pages/doc7300.aspx

ICAO. (2020). CORSIA Frequently asked questions. Retrieved November 06, 2020, from https://www.icao.int/environmental-protection/CORSIA/ Pages/CORSIA-FAQs.aspx

ICC. (2019). ICC signs partnership at COP25 to support a carbon neutral aviation industry. Retrieved November 14, 2020, from https://iccwbo.org/media-wall/news-speeches/icc-signs-partnership-atcop25-to-support-a-carbon-neutral-aviation-industry/

IEA. (2020). Aviation. International Energy Agency. Retrieved October 08, 2020, from https://www.iea.org/reports/aviation

IPCC. (2020). Aviation and the global atmosphere: Aviation fuels. Retrieved October 29, 2020, from https://archive.ipcc.ch/ipccreports/sres/aviation/ 109.htm

Macintosh, A., \& Wallace L. (2008). International aviation emissions to 2025: Can emissions be stabilised without restricting demand? Elsevier Energy Policy, 37(1): 264-273. https://doi.org/10.1016/j.enpol.2008.08.029

Mazareanu, E. (2020). Total fuel consumption of commercial airlines worldwide between 2005 and 2021 in billion gallons. Retrieved November 21, 2020, from https://www.statista.com/statistics/655057/fuel-consumption-ofairlines-worldwide/

Moore, M. D., \& Fredericks B. (2014). Miconceptions of electric propulsion aircraft and their emergent aviation markets. Conference Paper from American Institute of Aeronautics and Astronautics, January 13, 2014.

MTU. (2020). GE9X. Retrieved November 17, 2020, from https://www.mtu.de/ engines/commercial-aircraft-engines/widebody-jets/ge9x

Patt, A. (2019). Making flying actually sustainable. Retrieved October 03, 2020, from https://ethz.ch/en/news-and-events/eth- news/news/2019/06/blogsustainable-flying-patt.html

Rindlisbacher, T. (2020). Environmental protection. Lecture Management of Air Transport at ETH Zurich, April 29, 2020.

Rogelj, J., Shindell, D., Jiang, K., Fifita, S., Forster, P., Ginzburg, V., ... Vilarino, M. V. (2018). Mitigation pathways compatible with $1.5^{\circ} \mathrm{C}$ in the context of sustainable development. An IPCC Special Report on the impacts of global warming of $1.5^{\circ} \mathrm{C}$, In Press.

Rutherford, D. (2018). Size matters for aircraft fuel efficiency. Just not in the way that you think. Retrieved November 29, 2020, from https://theicct.org/ blog/staff/size-matters-for-aircraft-fuel-efficiency

SESAR. (2020a). About vision. Retrieved December 08, 2020, from https://www. sesarju.eu/vision 
SESAR. (2020b). Benefits environment. Retrieved December 08, 2020, from https://www.sesarju.eu/approach/environment

Sheffield. (2020). Meaning of ETOPS and how it works. Retrieved October 24, 2020, from https://www.sheffield.com/articles/etops-and-how-it-works

Sieber, J. (2020). Die Antriebe der Zukunft - Auf dem Weg zur emissionsfreien Luftfahrt. [The propulsion of the future - On the way to emission-free aviation]. DGLR Luft- \& Raumfahrt Mitgliedermagazin Ausgabe Nr. 4 Oktober - Dezember 2020

Skybrary. (2017). 4D trajectory concept. Retrieved October 27, 2020 from https://www.skybrary.aero/index.php/4D_Trajectory_Concept

Skyguide. (2020). Environmental report 2019. Skyguide. Retrieved from https://www.skyguide.ch/wp-content/uploads/fileadmin/webpublications/ 2019-environmental-report/en/mobile/index.html

Tani, C. (2017). Auditors: 'Single European Sky' failed to meet main objectives. Retrieved December 01, 2017, from https://euobserver.com/science/ 140111

Todorov, T. (2019). Free route airspace developments in ICAO EUR regionConcept, implementation and support. ATM SG/5, Presentation date 01.12.2019.

Vollebergh, H. R. J., \& Brink C. (2020). What can we learn from EU ETS?, ifo DICE Report $181 / 2020$ (Spring): Carbon Pricing, ifo Institute 2020. Retrieved from https://www.ifo.de/publikationen/2020/aufsatzzeitschrift/what-can-we-learn-eu-ets

Wild, P. (2018). Practical carbon emission approaches, Unpublished documents, Aerospace Project Development Group, Dr. Peter Wild, WildVenture $\mathrm{GmbH}$.

Wild, P. (2020). Airline economics. Lecture Management of Air Transport at ETH Zurich, March 07, 2020.

ZeroAvia. (2020, September 25) ZeroAvia completes world first hydrogenelectric passenger plane flight. Retrieved from https://www.zeroavia.com/press-release-25-09-2020 


\begin{tabular}{ll} 
& \multicolumn{1}{c}{ Abbreviations } \\
ANS $=$ & Air Navigation Services \\
APU $=$ & Auxiliary Power Unit \\
ATM $=$ & Air Traffic Management \\
BPR $=$ & Bypass Ratio \\
CORSIA $=$ & Carbon Offsetting andReduction Scheme for International Aviation \\
EASA $=$ & European Union Aviation Safety Agency \\
ETOPS $=$ & Extended-range Twin-engine Operational Performance Standards \\
EU ETS $=$ & European Emission Trading System \\
FIR $=$ & Flight Information Region \\
FRA $=$ & Free Route Airspaces \\
GPU $=$ & Ground Power Unit \\
IATA $=$ & International Air Transport Association \\
ICAO $=$ & International Civil Aviation Organization \\
PEM $=$ & Proton-Exchanged Membrane \\
SAF $=$ & Sustainable Aviation Fuel \\
SESAR $=$ & Single European Sky ATM Research \\
VAT $=$ & Value Added Tax
\end{tabular}

